\title{
Case Study of The Phubbing Action of UIN Sunan Kalijaga Students in An Online Lecture
}

\author{
Wahyu Hidayat, Aninditya Sri Nugraheni \\ Universitas Islam Negeri Sunan Kalijaga \\ Jl. Laksda Adisucipto, Papringan, Caturtunggal, Kec. Depok, Kabupaten Sleman, Daerah Istimewa \\ Yogyakarta 55281 \\ Corresponding Email:wh988345@Gmail.com, anin.suka@Gmail.com
}

\begin{abstract}
The purpose of this study is to describe and reveal the impact of excessive smartphone use, which then leads to phubbing. This research study was conducted in May 2020 on 30 students of Uin Sunan Kalijaga as respondents or research subjects. This type of research is qualitative research and interviews with all research subjects, and literature review. The results of the study were recorded that $92 \%$ of 27 respondents revealed that a phubber did not give appreciation and was more likely to underestimate the other person. So, planting and practicing Pancasila values in everyday life is very important to carry out. This is so that each individual can fortify and organize himself against wise smartphone use. Then it is hoped that through this research study, students as the nation's next generation will realize the impact of excessive smartphone use on social life.
\end{abstract}

Keywords:

Phubbing, Smartphone, College Student

\begin{abstract}
Abstrak
Tujuan dari penelitian ini adalah untuk mendeskripsikan dan mengungkapkan dampak yang ditimbulkan dari penggunaan smartphone yang berlebihan, kemudian menyebabkan adanya tindakan Phubbing. Studi penelitian ini dilakukan pada bulan Mei 2020 terhadap 30 mahasiswa Uin Sunan Kalijaga sebagai responden atau subjek penelitian. Jenis penelitian ini adalah penelitian kualitatif dan wawancara terhadap semua subjek penelitian, dan kajian pustaka. Hasil dari penelitian tercatat 92\% sebanyak 27 responden mengungkapkan seorang Phubber tidak memberikan apresiasi dan lebih cenderung menyepelekan lawan bicara, tercatat data yang diperoleh $100 \%$ semua responden melakukakan Phubbing dan sangat bergantung pada penggunaan smartphone di setiap aktivitas. Maka, penanaman dan pengamalan nilai-nilai pancasila dalam kehidupan sehari-hari teramat penting untuk di laksanakan. Hal ini ditujukan agar setiap individu dapat membentengi dan mengatur dirinya terhadap penggunaan smartphone yang bijak. Kemudian diharapkan melalui studi penelitian ini, siswa dan mahasiswa sebagai generasi penerus bangsa akan menyadari dampak dari penggunaan smartphone yang berlebihan pada kehidupan sosial.
\end{abstract}

Kata kunci:

Phubbing, Smartphone, Mahasiswa

\section{A. PENDAHULUAN}

Revolusi Industri 4.0 memberikan kualitas jangkauan secara luas yang dapat diakses semua orang, mengakibatkan saling terhubungnya antara satu individu dengan individu lainnya melalui jaringan internet (secara online).

Hal tersebut dimanfaatkan oleh Kemendikbud dengan mengambil

langkah kontruktif $r$ terhadap
pembelajaran di perguruan tinggi
maupun di perguruan tinggi keagamaan
untuk melangkah lebih maju dalam
pemanfaatan teknologi jaringan dan
informasi di bidang pendidikan
Indonesia. Pemanfaatan terhadap
teknologi jaringan dan informasi, melalui


kemendikbud dan Jendral Perguruan Tinggi menghasilkan suatu website (pditt.belajar.kemendikbud.go.id). website tersebut berisikan banyak konten untuk sumber belajar.

Adanya inovasi pembaharuan terhadap proses pembelajaran di perguruan tinggi maupun perguruan tinggi keagamaan menjadikan perkuliahan dilaksanakan dengan daring (dalam jaringan). Perkuliahan secara daring (dalam jaringan) merupakan suatu metode pembelajaran online, dan melalui jaringan internet.

Semua interaksi pembelajaran didukung menggunakan media jaringan (Internet, LAN,dan WAN). Dengan adanya pembelajaran secara daring, diharapkan adanya peningkatan terhadap kualitas dan kuantitas perguruan tinggi di Indonesia, komukasi antara dosen dengan mahasiswa menjadi lebih intens, keterbukaan evaluasi terhadap media dan bahan ajar di dalam perkuliahan, dan peningkatan terhadap refensi dan umpan balik suatu keilmuan yang bersifat informatif. Namun adanya kontruksi pembelajaran tersebut menuntut sivitas akademika universitas saling terintregrasi yang diatur dalam jangka waktu tertentu melalui inisiasi, perencanaan, penjadwalan, pengawasan, penilaian, evaluasi, dan refleksi terhadap pembelajaran daring tersebut. Refleksi dari berbagai pihak sivitas akademika universitas menghasilkan hasil evaluasi yang berdampak baik dan buruk selama masa pembelajaran daring dilaksanakan. Adapun dampak postif dari adanya pembelajaran daring; meningkatnya interaksi antara dosen dengan mahasiswa, pembelajaran dapat dilakukan dimana saja, dan kapan saja, penyempurnaan terhadap materi pembelajaran menjadi lebih mudah. Disisi lainnya pembelajaran daring memiliki kekurangan; keterbatasan jaringan di suatu wilayah tertentu, psikologis Mahasiswa mengalami perubahan yang signifikan dikarenakan banyaknya suatu tugas yang diberikan oleh dosen, dan adanya tindakan Phubbing yang dilakukan mahasiswa ketika di lingkungan keluarga, universitas, dan masyarakat.

Adanya tindakan Phubbing di lingkungan keluarga, berdampak pada menurunnya pragmatis komunikasi antara orang tua dengan anak-anaknya. Oleh karena itu, hal tersebut menjadi penting untuk dibahas agar semua pihak, baik sivitas akademika (dosen), mahasiswa, dan keluarga saling bersinergi dan terintregrasi dengan baik. Maka dalam pembahasan penelitian ini, peneliti menitikberatkan pada kurang bijaknya penggunaan smartphone oleh mahasiswa yang mengakibatkan terjadinya kegiatan Phubbing tersebut. Adapun tujuan dari penelitian ini adalah menumbuhkan sikap saling menghormati, saling mengasihi, dan menghargai lawan bicara karena efektif suatu komunikasi dapat dicapai apabila mempunyai pengertian yang sama di dalam penyampaian suatu pesan antara komunikator dan komunikan. Adapun peranan dan pengamalan dari nilai-nilai Pancasila sangatlah penting bagi generasi bangsa karena Pancasila sebagai ideologi bangsa ini telah memberi pedoman bagi rakyat Indonesia dalam hidup berbangsa dan bernegara. Nilai-nilai yang terkandung di dalamnya merupakan benteng kehidupan dalam menghadapi efek globalisasi yang berkembang. Hal inilah yang diharapkan dapat diterapkan dalam kehidupan sehari-hari sebagai upaya untuk menanggulangi efek atau dampak dari perkembangan teknologi yang semakin modern seperti halnya Phubbing. Berdasarkan penjelasan diatas, melalui 
penelitian ini peneliti termotivasi untuk dapat mendeskripsikan, mengungkapkan, memberikan suatu solusi terhadap dampak kurang bijaknya penggunaan Smartphone dan tindakan Phubbing.

\section{B. METODE PENELITIAN}

Penelitian ini termasuk penelitian kualitatif, penelitian ini dilakukan guna menemukan suatu penanganan terhadap dampak yang ditimbulkan adanya tindakan Phubbing oleh mahasiswa pada perkuliahan daring. Sedangkan teknik pengumpulan data yang digunakan peneliti dalam penelitian ini adalah wawancara (secara daring maupun luring), dan kajian dokumen. peneliti melakukan kajian data berdasarkan studi kasus terhadap tindakan Phubbing tersebut, adapun data wawancara yang dihasilkan dari pengalaman setiap variabel terhadap studi kasus Phubbing tersebut untuk sebagai bahan dan kajian data dalam penelitian.

\section{LAHIRNYA ISTILAH PHUBBING}

Seiring dengan kemajuan teknologi informatika dan jaringan, komunikasi antara individu satu dengan individu lainnya mengalami suatu perubahan yang signifikan. Era digital pada saaat ini, memungkinkan individu satu dengan individu lainnya untuk bertatap muka secara langsung guna menyampaikan pesan. Adanya kemajuan perkembangan teknologi informasi dan jaringan, memunculkan suatu perangkat elektronik (Smartphone) yang dapat berguna, dan memudahkan kegiatan manusia. Penggunaan Smartphone ini semakin mengalami peningkatan, dibuktikan berdasarkan grafik dalam permintaan pada tahun 2018, melalui data yang tercatat pada IDC (International Data Corporation) Quarterly Mobile
Phone Tracker, mengalami peningkatan permintaan $18 \%$ dengan 9,4 juta unit.

Kemudahan yang didapatkan pengguna Smartphone antara lain; berinteraksi sosial dengan individu lainnya melalui banyak aplikasi (facebook, twitter, email, whatsapp, dll), berbelanja online, menelpon, membayar tagihan listrik, dan masih banyak yang lainnya. Namun adanya kemudahan dari adanya Smartphone, terdapat hal negatif yang ditimbukan dari penggunaan Smartphone tersebut seperti penglihatan terganggu, mempengaruhi kesehatan psikologis, dan adanya tindakan Phubbing.

Phone Snubbing atau yang dikenal dengan sebutan Phubbing merupakan suatu fenomena yang bersamaan dengan munculnya penggunaan Smartphone, dikenalkan oleh McCann seorang agensi periklanan, dan kata Phubbing tersebut sudah terdaftar di kamus Macquarie.

Sejak awal kemunculan Smartphone, banyak orang saling terhubung antara individu satu dengan lainnya di dunia maya. Namun semakin banyaknya penggunaan Smartphone tersebut menimbulkan masalah sosial baru. Banyak orang terhubung melalui adanya Smartphone di dunia maya, namun pada kenyataannya di dunia nyata banyak orang tidak terhubung dalam komunikasi setiap harinya.

Banyak orang mengacuhkan orang didepannya ketika sedang berkumpul, dan lebih memilih sibuk dengan Smartphone yang adan digenggamannya. Ketidakmampuan seseorang dalam mengontrol penggunaan Smartphone menjadi penyebab utama adanya phubbing. Hal itu menimbulkan adanya suatu adiksi (lost of control) dari psikologis pengguna smartphone tersebut. 
Taufik Hidayat selaku Kepala Bidang Layanan e- Government Dinas Komunikasi, Informasi dan Statistik (Diskominfo) Kota Semarang mengatakan istilah Phubbing mulai booming bersamaan dengan maraknya Smartphone yang tidak sekedar untuk telepon dan SMS (Short Message Service) tetapi juga mempunyai banyak aplikasi seperti game, jejaring sosial yang membuat orang betah berlama-lama memegang handphone. Di Indonesia sendiri, penelitian mengenai efek negatif ataupun kampanye sosial yang ditimbulkan karena adiksi terhadap Smartphone masih jarang sekali ditemui.

Adiksi dapat didefinisikan sebagai suatu pola perilaku yang dapat meningkatkan resiko penyakit dan masalah personal serta masalah sosial. Perilaku adiktif biasanya dialami secara subjektif sebagai "loss of control" dimana perilaku terus muncul meskipun telah adanya usaha untuk menghentikan perilaku tersebut. ${ }^{1}$

$$
\text { Menurut ungkapan Ratih }
$$

Andjayani Ibrahim seorang psikologi anak bahwasanya suatu adiksi yang ditimbulkan dari adanya kecanduan mengakibatkan seseorang anak merasa bosan dan sulit berkonsentrasi dengan dunia nyatanya, sulit mendengar nasehat orang lain. ${ }^{2}$

Adiksi dalam permasalahan ini dapat menimbulkan bahaya bagi kehidupan, hal ini menyebabkan adanya intovert (suka menyendiri) dan sulit berkomunikasi dengan orang-orang yang ada disekitarnya. Bahkan masalah lainpun bisa muncul, sebagaimana fenomena

${ }^{1}$ A. Said Hasan, 2014, “Kecenderungan internet addiction disorder mahasiswa fakultas dakwah dan komunikasi ditinjau dari religiositas", jurnal dakwah. Vol.XV No 2, 2004, 412.

${ }^{2}$ E.P. Sarafino, Health Psichology:

Biopsychosocial Interaction. (Singapore: John Willey \& Sons, 1990), hlm.37. yang banyak ditemukan di kehidupan sehari-hari. seperti mengabaikan lawan bicara saat melakukan interaksi sosial.

Ball-Rokeach and De-Fleur tahun 1976 dalam "Dependency Model of Mass Communication Effects" , menyatakan bahwa teori ini pada dasarnya memfokuskan perhatiannya pada kondisi struktural masyarakat yang mengatur kecenderungan terjadinya suatu efek media massa. Diasumsikan bahwa sifat dan bentuk pengaruh media massa pada khalayak pada dasarnya merupakan hasil interaksi dari tiga variabel yaitu ketergantungan khalayak pada media, kondisi struktural masyarakat dan kondisi atau sistem pelayanan media. ${ }^{3}$

Perubahan terhadap gaya hidup masyarakat dimulai sejak adanya globalisai yang sudah mengikat kehidupan manusia. Globalisasi yang sudah terjadi di seluruh dunia, berdampak pada meningkatnya penggunaan Smartphone. Bahkan mengkonstruksi pola hidup masyarakat sampai ke akar-akarnya. Misalnya pola hidup seorang remaja di era globalisasi tidak lepas dengan ketergantungan pada Smartphone, kecanggihan fitur-fitur inilah yang menjadi daya tarik dalam penggunaannya.

Seorang remaja menggunakan Smartphone tersebut tidak hanya untuk kebutuhan, melainkan digunakan untuk bergaya, dan mengikuti perkembangan zaman. Sehingga dampak yang ditimbulkan dari ketergantungan penggunaan Smartphone menjadikan seorang remaja menjadi lupa waktu, sibuk dengan Smartphone, lupa mengerjakan

\footnotetext{
${ }^{3}$ Widjayanti Santoso Mulyono, IImu Sosial: Perkembangan dan Tantangan di Indonesia, (Jakarta: Yayasan Pustaka Obor Indonesia, 2016) hlm. 214
} 
tugas sekolah, dan masih banyak yang lainnya. Hal tersebut menjadi kecemasan bagi orang tua melihat tidak bijaknya pernggunaan Smartphone di kalangan remaja saat ini. Melihat fenomena yang telah dipaparkan, penulis menelaah bagaimana fenomena Phubbing ini berkembang dimasyarakat terutama pada mahasiswa UIN Sunan Kalijaga Yogyakarta atas media baru seperti Smartphone, bagaimana penggunaan Smartphone secara bijak yang dilakukan mahasiswa pada perkuliahan bersifat daring.

\section{DESK?RIPSI PENELITIAN}

Studi Penelitian ini dilakukan pada bulan mei 2020 terhadap mahasiswa yang terdaftar di Fakultas Ilmu Tarbiyah dan Keguruan Universitas Islam Negeri (UIN) Sunan Kalijaga Yogyakarta, dengan responden yang berjumlah 30 orang yang terdiri dari sepuluh mahasiswa laki-laki dan dua puluh mahasiswi perempuan di beberapa jurusan (prodi). Data studi ini diperoleh dari wawancara kepada responden untuk menjaring data tentang pandapat mahasiswa yang berkaitan dengan fenomena Phubbing pada perilaku kehidupan mahasiswa khususnya dikalangan mahasiswa FITK UIN Sunan Kalijaga Yogyakarta. Dari data yang diperoleh dapat diidentifikasi beberapa pendapat mahasiswa tentang fenomena Phubbing terhadap perilaku kehidupan pada mahasiswa , antara lain:

1. Saluran yang digunakan.

2. Preferbilitas ketinggalan.

3. Perasaan Cemas terhadap Phubbing.

4. Mengetahui Phubbing.

5. Pelaku Phubbing.

6. Alasan Phubbing dilakukan.

7. Meminta izin kepada lawan bicara.
8. Perasaan Terganggu adanya Phubbing.

9. Peneguran terhadap pelaku Phubbing.

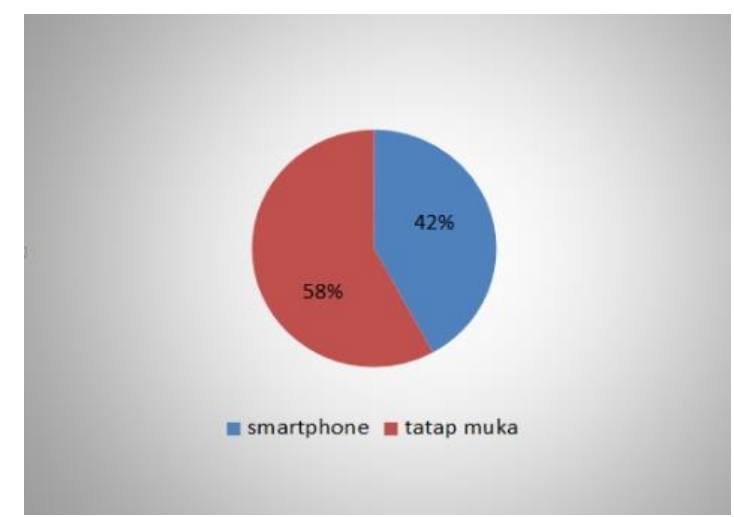

Gambar 1. Saluran yang digunakan

Kehadiran Smartphone di era globalisasi menambah kemudahan seseorang untuk berkomunikasi dengan lainnya tanpa tatap muka. Nampaknya, ungkapan ini sesuai dengan realita yaang terjadi sekarang ini.. Hal ini dapat terbukti dari hasil studi yang menunjukkan bahwa 12 responden memilih saluran berkomunikasi yang digunakan melalui Smartphone. Hal ini dikarenakan adanya ketergantungan terhadap Smartphone itu sendiri dan efisiensi waktu dan tenaga. Sedangkan sebanyak 18 responden tetap memilih berkomunikasi melalui tatap muka secara langsung dibandingkan melalui Smartphone karena berdampak pada kepuasan terhadap hasil yang diperoleh.

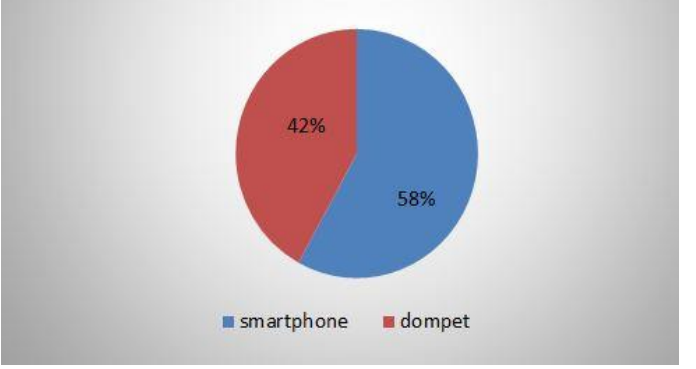

\section{Gambar 2. Preferbilitas Ketertinggalan}

Begitu berharga dan pentingnya smartphone bagi para penggunanya menjadikan mereka lebih memilih 
dompet yang harus tertinggal daripada ponsel pintarnya. Hal tersebut dibuktikan dari jawaban 11 responden. Hal ini dikarenakan sudah terbiasanya mereka menggunakan Smartphone setiap harinya baik untuk berbagi informasi, bersosial media, atau bermain game. Namun hal tersebut tidak dirasakan oleh 19 responden lainnya. Mereka lebih memilih dompet daripada Smartphone dikarenakan mereka lebih membutuhkannya, seperti KTP, SIM, KTM, ATM serta uang.

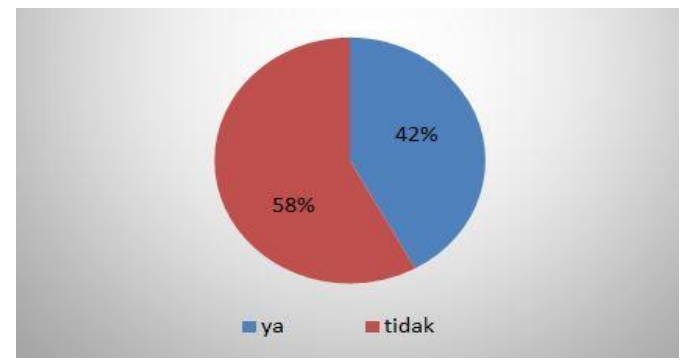

Gambar 3. Perasaan Cemas

$\begin{array}{lrr} & \text { Efek cemas merupakan dampak } \\ \text { yang ditimbulkan dari adanya } & \text { an } \\ \text { penggunaan Smartphone } & \text { secara }\end{array}$ berlebihan. Hal inilah yang dialami oleh 12 responden yang mengalami perasaan serupa. Perasaan cemas karena tidak mendapat berita-barita penting baik seputar perkuliahan atau media sosial yang sedang ramai diperbincangkan. Tetapi dalam wawancara ini 18 dari 30 responden tidak merasa cemas jika tidak menggunakannya dikarenakan rasa ketergantungan yang masih rendah terhadap Smartphone.

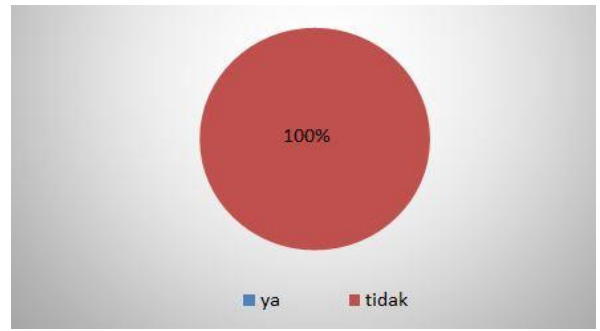

Gambar 4. Mengetahui Istilah Phubbing
Ketergantungan pada Smartphone menjadikan penggunanya menciptakan gangguan sosial seperti Phubbing. Tetapi dalam hal pengetahuan mengenai istilah Phubbing sendiri, semua responden yang berjumlah 30 orang belum mengetahui mengenai istilah tersebut.

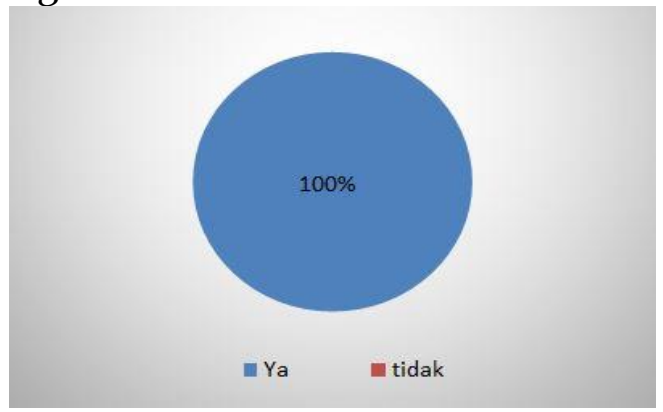

\section{Gambar 5. Pernah melakukan} Phubbing

Ketergantungan pada Smartphone menjadikan penggunanya menciptakan gangguan sosial seperti Phubbing. Hasil studi kami membuktikan bahwa semua responden yang kami wawancarai pernah menjadi seorang Phubber (sebutan untuk individu yang melakukan Phubbing) ketika mereka sedang kumpul bersama dengan keluarga, sahabat, dan teman.

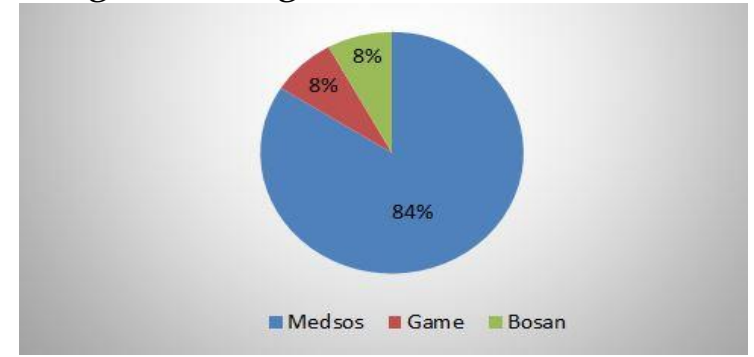

\section{Gambar 6. Alasan melakukan Phubbing}

$\begin{array}{ccr}\text { Berbagai } & \text { alasan } & \text { dalam } \\ \text { penggunaan } & \text { Smartphone } & \text { yang }\end{array}$
mengakibatkan kegiatan Phubbing dilakukan. Alasan terbesar ditemukan karena sudah tinnginya rasa ketergantungan terhadap Smartphone oleh media social seperti whatsapp (24 orang), yang kedua adalah untuk bermain game ( 3 orang). Terdapat ada (3 orang) juga alasan lain, dimana lawan bicara dianggap tidak menarik sehingga menjadikan responden merasa bosan. 


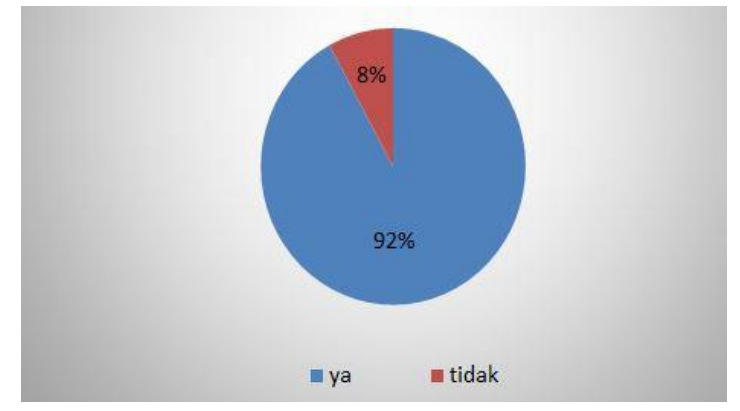

Gambar 7. Meminta izin kepada lawan bicara

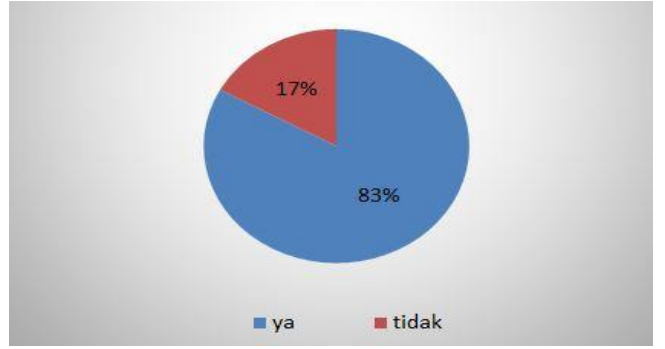

Gambar 8. Perasaan Terganggu

Berdasarkan permintaan izin sebelum menggunakan Smartphone, tercatat bahwasannya 9 responden memilih tidak meminta izin dalam penggunaan Smartphone tersebut. Sesuatu hal yang mereka anggap tidak begitu penting karena spontanitas perilaku para penggunanya. Sedangkan sisanya yaitu sebanyak 21 responden masih menghormati sesamanya dengan menjunjung etika dalam berinteraksi sosial dengan cara meminta izin terebih dahulu ketika hendak menggunakan Smartphone.

Menurut data mengenai terganggunya suatu komunikasi akibat adanya Phubbing menekankan bahwa seorang Phubber tidak memberikan apresiasi dan lebih cenderung untuk menyepelekan lawan bicara. Hal tersebut diperkuat dengan 27 responden yang merasa terganggu apabila komunikasi secara tatap muka dengan lawan bicara yang sedang menggunakan Smartphone. Namun, terdapat 3 responden yang menjawab tidak merasa terganggu sama sekali dengan adanya Phubbing. mereka beralasan bahwa mereka merupakan Phubber (pelaku Phubbing).

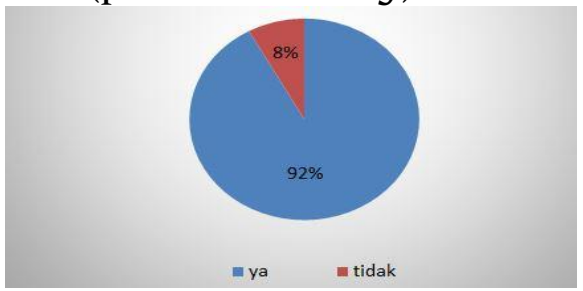

Gambar 9. Perlunya peneguran kepada pelaku Phubbing

27 dari 30 responden memilih perlu adanya peneguran terhadap para pelaku Phubbing untuk menindaklanjuti melebarnya fenomena Phubbing. Hal ini dikarenakan kesadaran mereka akan etika cara berkomunikasi yang baik. Sedangkan 3 responden lainnya memilih untuk tidak menegur atau membiarkan pelaku Phubbing dikarenakan dia sendiri merupakan salah satu pelaku Phubbing tersebut.

\section{E. PEMBAHASAN}

Berdasarkan perolehan data yang didapatkan penulis, bahwasannya banyak dampak positif yang ditimbulkan dengan adanya penggunaan Smartphone. Melalui adanya penggunaan Smartphone, memudahkan mahasiswa dalam sarana berkomunikasi sosial, saling adanya keterbukaan mengenai informasi proses perkuliahan, bermain game, memperoleh suatu informasi mengenai tentang perkuliahan, kedekatan mahasiswa satu dengan lainnya semakin meningkat, mahasiswa menjadi lebih produktif untuk menggali potensi keahlian baik dalam tulisan maupun yang lainnya. Munculnya internet sebagai dampak dari perkembangan teknologi di dunia komunikasi memungkinkan manusia untuk terhubung secara virtual sehingga dampaknya dapat kita rasakan yaitu lahirnya komunitas-komunitas virtual. Sehingga dengan berbagai bentuk kemudahan yang bisa didapatkan secara 
virtual itulah, penggunanya pun lebih memilih saluran berkomunikasi melalui Smartphone dibandingkan dengan saluran komunikasi tatap muka secara langsung. Hal ini juga akan berdampak pada perasaan bahwa Smartphone akan jauh lebih penting dan lebih berharga dari pada dompet mereka.

Dalam studi ini kami membuat indikator bagaimana seorang individu dapat dikatakan memiliki ketergantungan terhadap Smartphone. Indikator ini adalah kecemasan responden ketika tidak menggunakan smartphone, dimana sebanyak 12 responden menjawab bahwa mereka akan mengalami hal tersebut jika tidak menggunakan smartphone.

\section{Ketergantungan terhadap}

Smartphone pada akhirnya menjadikan penggunanya bersifat apatis. Sikap apatis merupakan mementingkan diri sendiri, mempunyai sikap acuh tak acuh, masa bodoh, dan tidak peduli. ${ }^{4}$ Hal ini dikarenakan mereka terlalu fokus pada apa yang ada didalam genggamannya.

Berdasarkan data yang diperoleh bahwasannya 30 responden tidak mengetahui adanya istilah Phubbing. Setelah semua responden mengetahuinya, semua responden pernah mengalami, dan melakukan tindakan Phubbing pada saat berkumpul dengan teman, sahabat, dan keluarga. Kemudian semua responden menyadari bahwasannya salah satu dampak negative yang ditimbulkan dari adanya Phubbing, mendekatkan seseorang yang jauh berada di suatu wilayah tertentu, dan menjauhkan seseorang yang ada di depan

4 Badan Pengembangan dan Pembinaan Bahasa, Kementerian Pendidikan dan Kebudayaan Republik Indonesia, KBBI Daring, https://kbbi.kemdikbud.go.id/entri/apatis diakses pada tanggal 25 Agustus 2019 pukul 20.02 responden ketika berkomunikasi secara langsung.

Fenomena Phubbing sebagai akibat dari perkembangan Smartphone dapat dianalisa menggunakan teori ketergantungan kecanduan terhadap media. Kecanduan (modern) didefinisikan sebagai kelekatan yang kompleks, progresif, berbahaya dan sering juga melumpuhkan terhadap zat psikoaktif (alkohol, heroin, zat adiktif berbahaya) atau perilaku (seks, kerja, judi) yang dengannya individu secara konsklusif mencari perubahan perasaan. ${ }^{5}$

Dari definisi tersebut dapat dikatakan bahwa kecanduan terhadap berbagai hal mempunyai kemiripan gejala, hanya saja berbeda dalam hal objek kecanduannya.

Gejala pola perilaku untuk menentukan apakah seseorang sudah bisa digolongkan sebagai pecandu atau belum diantaranya sebagai berikut;

1. Pikiran pecandu internet (gadget) terus menerus tertuju pada aktivitas berinternet dan sulit dibelokkan ke arah lain.

2. Adanya kecenderungan penggunaan waktu internet (gadget) yang terus bertambah demi meraih tingkat kepuasan yang sama dengan perasaan sebelumnya.

3. Kejadian yang bersangkutan secara berulang gagal untuk mengontrol untuk menghentikan penggunaan internet (gadget).

4. Adanya perasaaan tidak nyaman, murung, atau ceppat tersinggunga (marah) ketika yang bersangkutan berusaha menghentikan penggunaan inetrnet (gadget).

\footnotetext{
${ }^{5}$ Jarot wijanarko \& Esther Setiawati, Ayah Baik - Ibu Baik, (Jakarta Selatan: Keluarga Indonesia Bahagia, 2016), hlm.16.
} 
5. Adanya kecenderungan untuk tetap online melebihi dari waktu yang ditargetkan. ${ }^{6}$

Menurut McLuhan, seorang yang berasal dari Kanada, dan penulis buku yang berjudul Understanding Media mengungkapkan bahwasannya mengungkapkan bahwasannya teknologi dan media telah menciptakan suatu revolusi peradaban yang baru, sehingga masyarakat sangat bergantung pada adanya teknologi, dan hidupnya tatanan masyarakat tersebut dipengaruhi dari kualitas dan kuantitas kemampuan masyarakat dalam menggunakan teknologi. 7

Penyampaian yang baik melalui komunikasi secara langsung akan berdampak pada meningkatnya kedekatan antar individu. Sebanyak 9 responden menjawab bahwa mereka tidak meminta izin membuka Smartphone karena secara spontanitas dari perilaku mereka. Hal ini menunjukkan adanya pergantian masa bahwa pada awalnya manusialah yang menciptakan teknologi, pada saat ini teknologi berbalik dan mengambil alih, kemudian mempengaruhi semua yang dilakukan manusia.

Perspektif individu terhadap Smartphone yang pada mulanya dianggap membawa manfaat, kini melahirkan suatu fenomena yang disebut Phubbing. Berdasarkan teori ketergantungan atau kecanduan yang telah dipaparkan di atas, kita dapat melihat bagaimana orang menjadi sangat bergantung pada Smartphone (media) untuk mendapatkan berbagai kebutuhan.

${ }^{6}$ Jarot Wijanarko \& Esther Setiawati, Ayah Baik - Ibu Baik, (Jakarta Selatan: Keluarga Indonesia Bahagia, 2016), hlm.16.

${ }^{7}$ Morrisan, dkk, Teori Komunikasi Massa, (Bogor: Ghalia Indonesia, 2010)
Interaksi sosial dapat berjalan dengan baik melalui adanya suda syarat, yaitu kontak sosial dan komunikasi. Kontak sosial menurut Ilmu Sosiologi, adanya unsur timbal balik dalam bentuk suatu isyarat antara si pelaku dan si penerima. Sedangkan komunikasi merupakan proses interaksi dan penyampaian suatu pesan melalui saluran atau media dari komunikator kepada komunikan. ${ }^{8}$

Dalam buku yang berjudul Psikologi Komunikasi karya Jalaluddin mengungkapkan, efektif suatu komunikasi dapat dicapai apabila mempunyai pengertian yang sama di dalam penyampaian suatu pesan antara komunikator dan komunikan. Selain itu komunikasi tersebut menghasilkan suatu kesenangan, dan mempengaruhi suatu tindakan dan sikap. ${ }^{9}$

Kebudayaan dan adat istiadat masyarakat Indonesia sudah dikenal dengan santunnya dalam berkomunikasi, dan menghormati lawan bicaranya. Namun pada kenyataan saat ini, penggunaan Smartphone mengkontruksi kebudayaan masyarakat Indonesia terutama yang bertempat tinggal didaerah perkotaan. Menurut hasil penelitian, semua responden berpendapat sama tentang penggunaan Smartphone yang dianggap suatu hal yang tidak baik saat percakapan sedang berlangsung.

Adiksi terhadap Smartphone membuat relasi kepada orang lain akan menjadi buruk. Perhatiannya yang semata-mata tertuju pada kesenangan diri dan internet (Smartphone)

\footnotetext{
${ }^{8}$ Soerjono Soekanto, Sosiologi: Satu Pengantar, ( Rajawali Pers, 1990)

9 Edoparnando, Komunikasi Efektif, https://edoparnando27.wordpress.com/komunikasiefetif/, diakses pada tanggal 28 Agustus 2019 pukul 19.23
} 
membuatnya kurang peduli terhadap kebutuhan orang lain. Menurut Edward T. Welch, salah satu ciri utama orang yang mengalami adiksi adalah menyalahkan orang lain dan gagal membangun relasi. ${ }^{10}$ Sudah pasti ia tidak dapat memberi perhatian atau peduli terhadap orang lain karena perilakunya tersebut. Atau dapat dikatakan bahwa orang yang terkena adiksi terhadap Smartphone akan mengakibatkan sikap anti sosial. Sikap ini diartikan sebagai sikap menentang kepada aturan-aturan atau norma-norma yang sedang berlaku di masyarakat. Nilainilai dan norma yang terdapat dalam masyarakat merupakan ciri kemapanan manusia yang menginginkan keteraturan dalam kehidupannya. Adapun orangorang yang antisosial berarti sebaliknya, yaitu tidak menginginkan adanya kemampanan tersebut. ${ }^{11}$

Walaupun orang yang melakukan Phubbing tidak menyadari hal ini, namun dampak yang akan dihasilkan akan begitu dirasakan oleh orang yang berada disekitarnya. Hal ini akan begitu dirasakan dampaknya manakala perilaku Phubbing ini terjadi di ruang publik. Misalnya, ketika kita barada dalam bis kota, yang mana di depan atau di sekitar kita terdapat orang yang lebih tua atau lebih membutuhkan tempat duduk, sedang kita asyik dengan Smartphone ada di genggaman kita, maka sikap itu akan sangat dirasakan dampaknya oleh orang sekitar. Padahal norma-norma yang telah dijunjung tinggi oleh para pendahulu bangsa ini seperti saling menghormati, saling mengasihi dan menyayangi akan berganti menjadi sikap individualis yang apatis terhadap orang lain, yang mana

\footnotetext{
${ }^{10}$ Jarot Wijanarko \& Esther Setiawati, Ayah Baik ..., hlm.16.

${ }^{11}$ Bagja Waluya, Sosiologi: Menyelami Fenomena Sosial di Masyatrakat, (Bandung: PT. Setia Purna Inves, 2007), hlm.103.
}

norma ini tidak sesuai dengan apa yang ada di tengah masyarakat kita.

Sebagai pemersatu bangsa, Pancasila mutlak diperlukan oleh seluruh generasi bangsa. Sekalipun bangsa Indonesia yang sekarang sudah bersatu, tidak berarti pancasila tidak diperlukan lagi. Karena yang disebut bangsa Indonesia bukan hanya yang sekarang ini ada, tetapi juga yang nanti akan ada. Selama masih terjadi proses regenerasi, selama itu pula pancasila sebagai pemersatu bangsa masih tetap kita perlukan. Itu berarti, selama masih ada bangsa Indonesia, selama itu pula masih kita perlukan alat pemersatu bangsa.Hal Ini sekaligus membuktikan kebenaran Pancasila, baik selaku dasar negara, maupun sebagai kepentingan lain. Sehingga pancasila memiliki banyak fungsi.

Pancasila sebagai ideologi bangsa ini telah memberi pedoman bagi rakyat Indonesia sendiri dalam hidup berbangsa dan bernegara. Nilai-nilai yang terkandung di dalamnya merupakan benteng kehidupan dalam menghadapi efek globalisasi yang berkembang. Diantara nilai-nilai yang terkandung dalam pancasila adalah sebagai berkut:

1. Menempatkan persatuan, kesatuan, kepentingan, keselamatan bangsa dan negara di atas kepentingan pribadi atau golongan.

2. Menghormati hak orang lain

3. Suka memberi pertolongan kepada orang lain

4. Memajukan pergaulan demi persatuan dan kesatuan bangsa yang Bhineka Tunggal Ika. ${ }^{12}$

\footnotetext{
12 Direktorat Jenderal Pembelajaran dan Kemahasiswaan Kementerian Riset Teknologi dan Pendidikan Tinggi, Pendidikan Pancasila untuk Perguruan Tinggi, (Jakarta: 2016), hlm. 187-188.
} 
Selain nilai-nilai diatas, sistem etika yang berlandaskan pada semangat kebersamaan, solidaritas sosial akan melahirkan kekuatan untuk menghadapi penetrasi nilai yang bersifat memecah belah bangsa. Hal inilah yang diharapkan dapat diterapkan dalam kehidupan sehari-hari sebagai upaya untuk menanggulangi efek atau dampak dari perkembangan teknologi yang semakin modern seperti halnya Phubbing.

\section{F. KESIMPULAN}

Penelitian ini dilakukan karena penulis melihat, mengalami, dan merasakan dari berbagai permasalahan mengenai kurang bijaknya penggunaan Smartphone di berbagai penjuru negara ini. Kemudian apakah fenomena serupa juga terjadi di Yogyakarta khususnya di Fakultas Ilmu Tarbiyah dan Keguruan (FITK) Universitas Islam Negeri Sunan Kalijaga Yogyakarta. Untuk menganalisa hal tersebut maka dibutuhkan studi atau pendekatan ilmiah dan beberapa pemikiran para tokoh. Dengan suatu metode studi kasus dapat memperoleh penjelasan atas suatu fenomena Phubbing tersebut. Diharapkan melalui studi ini mahasiswa yang notabennya merupakan generasi penerus bangsa menyadari dampak penggunaan Smartphone yang berlebihan terhadap kehidupan sosial.

Hasil studi secara umum menjelaskan bahwa mahasiswa UIN Sunan Kalijaga Yogyakarta, juga mengalami fenomena Phubbing yang disebabkan karena adanya ketergantungan terhadap penggunaan Smartphone yang cukup tinggi. Ketergantungan ini disebabkan karena kemudahan yang disediakan oleh Smartphone disetiap gerak kehidupannya untuk melakukan berbagai kegiatan.

$$
\text { Jika masyarakat terutama }
$$

mahasiswa belum dapat bijak dalam menggunakan Smartphone maka akan menimbulkan beberapa efek salah satunya adalah menurunnya kepekaan terhadap lingkungan atau dapat dikatakan sebagai sikap apatis atau anti sosial.

Dalam hal ini, kita tidak dapat menolak mengenai hadirnya teknologi dan komunikasi yang ada. Tetapi tidak menutup kemungkinan untuk mengurangi adanya sesuatu yang buruk terjadi. Jika terdapat keterpaksaan untuk membuka Smartphone saat adanya komunikasi, ada baiknya untuk meminta izin terlebih dahulu agar lawan bicara merasa masih tetap dihargai keberadaannya. Selain itu penggunaannya juga tidak dilakukan sepanjang pembicaraan berlangsung. Dan adanya kesadaran diri masing masing individu untuk saling mengingatkan agar tidak berlebihan dalam penggunaan Smartphone.

Penanaman dan pengamalan nilai-nilai pancasila dalam kehidupan sehari-hari teramat penting untuk di laksanakan. Hal ini ditujukan agar dapat membentengi setiap individu dalam menghadapi tantangan global yang dapat mengancam keutuhan dan kesatuan NKRI. 


\section{G. DOKUMEN PENELITIAN}
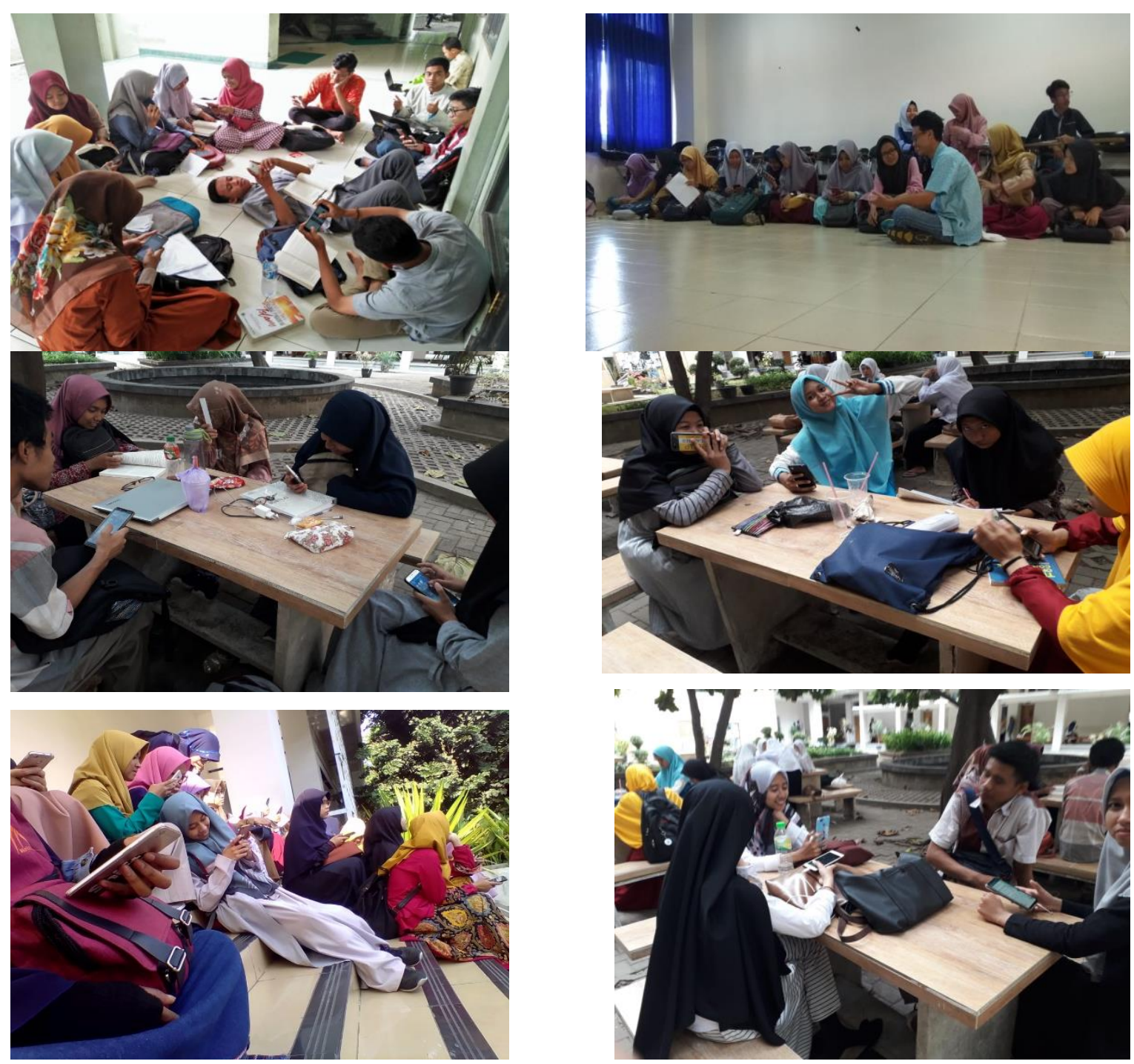

Foto para mahasiswa tampak sibuk bermain smartphone sendiri pada saat berkumpul (Phubbing). 


\section{DAFTAR PUSTAKA}

Kementerian Riset Teknologi dan Pendidikan Tinggi, Direktoran Jenderal Pembelajaran dan Kemahasiswaan. Pendidikan Pancasila untuk Perguruan

Tinggi. Jakarta: Kementerian Riset Teknologi dan Pendidikan Tinggi, 2016.

Morrisan, dkk. Teori Komunikasi Massa. Bogor: Ghalia Indonesia, 2010

Soerjono Soekanto.1990. Sosiologi: Satu Pengantar. Jakarta: Rajawali Pers

Sarafino, E.P. Health Psichology Biopsychosocial Interaction. Singapore: John Willey \& Sons, 1990.

Sukari. Guru bukan Tersangka. Gresik: Caremedia Cummunication

Widjayanti Santoso Mulyono. 2016. Ilmu Sosial: Perkembangan dan

Tantangan di Indonesia. Jakarta: Yayasan Pustaka Obor Indonesia, 2017. Waluya , Bagja. Sosiologi: Menyelami Fenomena Sosial di Masyatrakat. Bandung: PT. Setia Purna Inves, 2007.

Wijanarko, Jarot \& Setiawati, Esther. Ayah

Baik - Ibu Baik. Jakarta Selatan: Keluarga Indonesia

Bahagia, 2016.

Hasan, A . Said. 2014. "Kecenderungan internet addiction disorder mahasiswa

fakultas dakwah dan komunikasi ditinjau dari religiositas”, jurnal dakwah.Vol.XV No 2, 2004

Badan Pengembangan dan Pembinaan Bahasa, Kementerian Pendidikan dan Kebudayaan

Republik Indonesia, KBBI Daring, https://kbbi.kemdikbud.go.id/ent ri/apatis diakses pada tanggal 25 Agustus 2019 pukul 20.02

Harty, Irene, Phubbing istilah untuk orang yang lebih fokuskan gawai daripada sekitar,

http://mediaindonesia.com/read/ detail/163474-phubbing-istilah untuk-orang-yang-lebih-

fokuskan-gawai-daripada-sekitar, pada tanggal 21

Agustus 2019 pukul 19.12

Khoirunnisa. Top 5 vendor smartphone di Indonesia Q2 2018. http://seluler .id /2018/ o9/idc-top-5-vendorsmartphone-di-indonesia-Q2-2018. Pada tanggal 22 Agustus 2019 pukul 20.13

Edoparnando, Komunikasi Efektif, https://edoparnando27.wordpress. com/komunikasi-efetif/, diakses pada tanggal 28 Agustus 2019 pukul 19.23 